\title{
Cloning, characterization and sequencing of two haemagglutinin genes from Eikenella corrodens
}

\author{
Venkatarama K. Rao, Joan A. Whitlock and Ann Progulske-Fox* \\ Department of Oral Biology and Periodontal Disease Research Center, University of Florida, Gainesville, \\ Florida 32610, USA
}

(Received 10 July 1992; accepted 11 August 1992)

\begin{abstract}
Eikenella corrodens is emerging as an important human pathogen, in both extra-oral and periodontal infections. From a clone bank of Eikenella corrodens chromosomal DNA produced in Escherichia coli JM109, twenty-two clones expressed Eikenella antigens and of these, two expressed functional haemagglutinins. By virtue of different restriction maps and a lack of homology by Southern hybridization, the two cloned fragments encoding the two haemagglutinins have been shown to be distinct. Maxicell analysis revealed that clone 1, carrying plasmid pVKR201, produces three Eikenella proteins, one of $31.5 \mathrm{kDa}$ and two of approximately $14 \mathrm{kDa}$ each. Expression of each of the proteins appears to be under the control of an Eikenella promoter(s). Clone 2, carrying plasmid pVKR301, produces two proteins, one of $93 \mathrm{kDa}$ and the second of $17 \mathrm{kDa}$. Expression of both of these proteins in $E$. coli requires the lac promoter in the vector. By preparing a series of subclones and testing each by maxicell analysis and for haemagglutination activity, a functional map of the insert of clone 1 was deduced and the $31.5 \mathrm{kDa}$ polypeptide identified as the haemagglutinin. Using similar methods, the $17 \mathrm{kDa}$ protein was found to be the haemagglutinin of clone 2. The nucleotide sequences of both haemagglutinin genes were determined and are presented. Computer analysis revealed no homology between the two haemagglutinins, and no homology to any previously sequenced proteins. These are the first genes of this genus to be cloned and sequenced.
\end{abstract}

\section{Introduction}

Eikenella corrodens is a Gram-negative, microaerophilic rod which was first described by Henriksen (1948) and later studied in more detail by Eiken (1958). Characterized by the unusual ability to pit or 'corrode' the agar surface, this bacterium was regarded mainly as a microbiological curiosity until relatively recently. Partly because of improved culture techniques, Eik. corrodens, which colonizes the upper respiratory tract and oral cavity of humans (Henriksen, 1969; Tanner et al., 1979), has, more recently, been recognized as an important opportunistic pathogen (Brooks et al., 1974; DeMello \& Leonard, 1979; Stoloff \& Gillies, 1986). It has been isolated from a variety of infectious processes, including abscesses of the thyroid (Vichyanond et al.,

*Author for correspondence. Tel. (904) 392 4370; fax (904) 392 3070; e-mail APFOX@CACTUS.STAT.UFL.EDU.

The nucleotide sequences reported in this paper have been submitted to EMBL database and have been assigned the accession number Z12610.
1983; Cheng et al., 1988a), brain (Drake \& Fischer, 1986; Cheng et al., 1988 b), liver (Hofstad \& Horn, 1989; Massey, 1989), osteomyelitis (Jones \& Romig, 1979; Farrington et al., 1983; Stoloff \& Gillies, 1986), chorioamnionitis (Sporken et al., 1985), septic arthritis (Flesher \& Bottone, 1989) and endocarditis (Sobel et al., 1981; Landis \& Korver, 1983; Decker et al., 1986). In addition, Eikenella is regarded as an important cause of infection following human bite wounds (Schmidt \& Herkman, 1983; Stoloff \& Gillies, 1986). Although frequently isolated as part of a polymicrobial process, Eik. corrodens has been isolated as the sole infecting agent in cases of meningitis, endocarditis and osteomyelitis (Jones \& Romig, 1979). Eik. corrodens is also associated with certain forms of periodontal disease and is considered an important contributor to tissue destruction and alveolar bone loss in this complex infectious process (Listgarten et al., 1978; Tanner et al., 1979; Dzink et al., 1985; Mattison et al., 1987).

Despite increasing evidence as to the importance of Eikenella as a human pathogen, relatively little information is available on the mechanisms by which it causes disease. Among the potential factors critical in the 
virulence of Eik. corrodens are its endotoxin, which is a potent stimulator of bone resorption (Progulske et al., 1984; Mattison et al., 1987), and slime, which has a strong immunosuppressive effect (Behling et al., 1979). For mucosal pathogens such as Eik. corrodens, the first step in the pathogenic process is the attachment or adherence of the bacterium to the mucosal surface (Gibbons \& Houte, 1975). For many pathogens, including the uropathogenic Escherichia coli (LabigneRoussel et al., 1985), Bordetella pertussis (Weiss \& Hewlett, 1986), Vibrio cholerae (Jones \& Freter, 1976), and Salmonella typhimurium (Jones \& Richardson, 1981), the ability to adhere to host tissues has been correlated with the ability to agglutinate erythrocytes. These studies have suggested that the haemagglutinin(s) of these organisms function as adhesins during the infectious process. Ebisu \& Okada (1983) showed that Eik. corrodens can agglutinate neuraminidase-treated erythrocytes. Neuraminidase, which is present in human saliva, is believed to potentiate bacterial adherence to human cells by exposing underlying carbohydrate receptors, known as cryptitopes, on host cells (Gibbons, 1989). In addition, Eik. corrodens has been shown to adhere in a similar fashion to neuraminidase-treated human buccal epithelial cells (Yamazaki et al., 1981) and guinea-pig macrophages (Miki et al., 1986). More recently, Yamazaki et al. (1988) have reported the partial purification of a lectin-like substance believed to be the haemagglutinin and adhesin of Eik. corrodens. This substance was characterized as a high-molecular-mass complex, which upon reduction with $\beta$-mercaptoethanol could be separated into several protein bands, suggesting either that the haemagglutinin was only partially pure, or that it was a multimeric complex linked by disulphide bonds.

With the advent of molecular biology techniques, it has become possible to identify and characterize in more detail putative virulence factors from a variety of pathogenic micro-organisms. We here report the cloning, characterization, sequencing and expression in E. coli of two distinct genes from the chromosome of Eik. corrodens ATCC 23834 which are capable of conferring upon $E$. coli JM109 the ability to agglutinate neuraminidase-treated erythrocytes.

\section{Methods}

Bacterial strains, plasmids, media and growth conditions. Eikenella corrodens ATCC 23834 (the type strain) was grown and maintained on blood agar plates ( $40 \mathrm{~g}$ trypticase soy agar $\mathrm{l}^{-1}$ and $5 \%, \mathrm{v} / \mathrm{v}$, defibrinated sheep blood). Growth was at $37^{\circ} \mathrm{C}$ in an atmosphere containing $10 \%$ $\mathrm{CO}_{2}$ and cells were transferred to fresh plates every 2-3 d. Liquid cultures were prepared using BY broth as described previously (Progulske \& Holt, 1987). Purity was assessed by Gram-staining, darkfield microscopy, and culture on blood agar plates.
Escherichia coli JM109 (recAl endAI gyrA96 thi-1 hsdRI7 supE44 relAl $\triangle($ lac-pro $A B)\left\{\mathrm{F}^{\prime}\right.$ traD36 proAB lacI $\left.\left.{ }^{9} Z \Delta \mathrm{M} 15\right\}\right)$ was used for all cloning studies and was cultured aerobically on Luria-Bertani (LB) medium consisting of Bactotryptone $\left(10 \mathrm{~g} \mathrm{l}^{-1}\right)$, Bacto-yeast extract $(5 \mathrm{~g}$ $\left.1^{-1}\right)$ and $\mathrm{NaCl}\left(10 \mathrm{~g} \mathrm{l}^{-1}\right)$. E. coli JM109 transformants were maintained on LB medium supplemented with ampicillin $\left(50 \mu \mathrm{g} \mathrm{ml}^{-1}\right)$.

Plasmid pUC9 (Yanisch-Perron et al., 1985) was used for construction of the genomic library and was a gift of $\mathbf{J}$. Messing. Plasmid pUC19, used for subcloning experiments, was purchased from Bethesda Research Laboratories. Plasmid pUC18 lacking the deletion mutation (Lobet et al., 1989) was also used for subcloning and was purchased from Pharmacia LKB Biotechnology. Plasmids produced during this work are listed in Table 1.

DNA preparation. Chromosomal DNA was isolated from Eik. corrodens ATCC 23834 by a modification of the method of A. Das (personal communication) as previously described (Progulske-Fox et al., 1989).

Plasmid DNA was routinely isolated by the rapid method of IshHorowicz \& Burke (1981). Larger, highly purified quantities of plasmid for ligation and sequencing were prepared by isopycnic centrifugation in a gradient of $\mathrm{CsCl}$ in the presence of ethidium bromide. Ethidium bromide was removed from the DNA by extraction with isobutanol followed by dialysis against $\mathrm{TE}$ buffer to remove $\mathrm{CsCl}$ and other lowmolecular-mass contaminants (Sambrook et al., 1989).

Construction of genomic libraries. Purified chromosomal DNA from Eik. corrodens was partially digested with HindIII so as to obtain fragments ranging in size from 2 to $10 \mathrm{~kb}$ as determined by agarose gel electrophoresis. These fragments were then ligated to dephosphorylated HindIII-cut pUC9 using T4 DNA ligase according to standard methods (Sambrook et al., 1989). Recombinant plasmids were used to transform E. coli JM109 made competent by the method of A. Das (personal communication) as described previously (Progulske-Fox et al., 1989). White colonies were picked and plated onto LB agar containing ampicillin and X-Gal to confirm the Lac ${ }^{-}$phenotype. All transformants

Table 1. Bacterial plasmids used in this study

\begin{tabular}{|c|c|}
\hline Plasmid & Characteristics $\dagger$ \\
\hline pUC series* & $\mathrm{Ap}^{\mathrm{R}} \operatorname{lac} Z^{+}$ \\
\hline pVKR201 & $\begin{array}{l}\mathrm{Ap}^{\mathrm{R}} \mathrm{HA}^{+} ; \mathrm{pUC} 9 \Omega(\text { HindIII } 3.6 \mathrm{~kb} \text { insert from Eik. } \\
\text { corrodens } 23834)\end{array}$ \\
\hline pVKR202 & $\begin{array}{l}\mathrm{Ap}^{\mathrm{R}} \mathrm{HA}^{+} \text {; pUC19 } \Omega(\text { HindIII } 3.6 \mathrm{~kb} \text {, orientation } \\
\text { opposite to that of pVKR201) }\end{array}$ \\
\hline pVKR203 & $\mathrm{Ap}^{\mathrm{R}} \mathrm{HA}^{+} ; \mathrm{pUC1} \Omega($ EcoRI-HindIII $1.9 \mathrm{~kb})$ \\
\hline pVKR204 & $\mathrm{Ap}^{\mathrm{R}} \mathrm{HA}^{+} ; \mathrm{pUCl} 9 \Omega($ HindIII-EcoRI $1.7 \mathrm{~kb})$ \\
\hline pVKR206 & $\mathrm{Ap}^{\mathrm{R}} ; \mathrm{pUC} 19 \Omega($ HindIII-KpnI $1 \cdot 2 \mathrm{~kb})$ \\
\hline pVKR207 & $\mathrm{Ap}^{\mathrm{R}} \mathrm{HA}^{+} ; \mathrm{pUC1} 9 \Omega(K p n \mathrm{I} 0.7 \mathrm{~kb})$ \\
\hline pVKR210 & $\mathrm{Ap}^{\mathrm{R}} \mathrm{HA}^{+} ; \mathrm{pUC1} 8 \Omega($ SstI-HincII $1.2 \mathrm{~kb})$ \\
\hline pVKR301 & $\begin{array}{l}\mathrm{Ap}^{\mathrm{R}} \mathrm{HA}^{+} ; \text {pUC9 } \Omega \text { (HindIII } 3.7 \mathrm{~kb} \text { insert from Eik. } \\
\text { corrodens } 23834)\end{array}$ \\
\hline pVKR302 & $\begin{array}{l}\mathrm{Ap}^{\mathrm{R}} ; \mathrm{pUC} 19 \Omega(\text { HindIII } 3.7 \mathrm{~kb} \text {, orientation } \\
\text { opposite to that of pVKR } 301)\end{array}$ \\
\hline pVKR303 & $\mathrm{Ap}^{\mathrm{R}} ;$ pUC19 $\Omega($ HindIII-HincII $1.6 \mathrm{~kb})$ \\
\hline pVKR304 & $\mathrm{Ap}^{\mathrm{R}} \mathrm{HA}^{+} ;$pUC18 $\Omega($ HincII-HindIII $1.4 \mathrm{~kb})$ \\
\hline pVKR305 & $\mathrm{Ap}^{\mathrm{R}} ; \mathrm{pUC1} 9 \Omega($ HindIII-EcoRI $0.7 \mathrm{~kb})$ \\
\hline pVKR306 & $\mathrm{Ap}^{\mathrm{R}} \mathrm{HA}^{+} ; \mathrm{pUC18} \Omega($ EcoRI-HindIII $2.4 \mathrm{~kb})$ \\
\hline pVKR308 & $\mathrm{Ap}^{\mathrm{R}} ; \mathrm{pUC19} \Omega(E c o$ RI $0.6 \mathrm{~kb})$ \\
\hline
\end{tabular}

* Characteristics described by Yanisch-Perron et al. (1985). All the other plasmids were produced during this work.

$\dagger \mathrm{HA}^{+}$, confers haemagglutination activity on $E$. coli JM109. $\Omega$ indicates the insert carried (details in parentheses). 
containing recombinant plasmids were stored at $-70{ }^{\circ} \mathrm{C}$ in $\mathrm{LB}$ broth containing ampicillin $\left(50 \mu \mathrm{g} \mathrm{ml}^{-1}\right)$ and glycerol $(20 \%, \mathrm{v} / \mathrm{v})$.

Preparation of antisera. Broth-grown cells of Eik. corrodens ATCC 23834 were prepared as described previously (Progulske-Fox et al., 1989 ) and used to inoculate adult New Zealand White rabbits. Each rabbit was given a booster dose 50-60 d later. Antisera were collected prior to the first immunization and at various intervals beginning one week after the booster dose. Sera were stored at $-20^{\circ} \mathrm{C}$. Polyclonal rabbit anti-Eik. corrodens sera were absorbed four times with $E$. coli JM109(pUC9) and the titre determined as described previously (Progulske-Fox et al., 1989).

Colony immunoblotting assay. Ampicillin-resistant transformants containing recombinant plasmids were spotted onto LB plates containing ampicillin. After $24 \mathrm{~h}$ of growth, the colonies were blotted onto nitrocellulose filters $(0.45 \mu \mathrm{m})$. Eik. corrodens and $E$. coli JM109(pUC9) were also spotted onto each filter as positive and negative controls respectively. Duplicate nitrocellulose filter imprints of each set of colonies were prepared and the cells on one of each pair were lysed by a $15 \mathrm{~min}$ exposure to chloroform vapour. Antigen-positive clones were detected as previously described (Progulske-Fox et al., 1989), but utilizing rabbit polyclonal Eik. corrodens antisera as the primary antibody. Clones which reacted positively in this assay were picked, regrown and retested by the same procedure.

Haemagglutination assay. Haemagglutination assays were carried out generally as described by Ebisu \& Okada (1983), using V-bottomed microtitre plates (Dynatech Laboratories). E. coli transformants expressing Eik. corrodens antigens as well as an appropriate $E$. coli control were grown overnight in LB broth containing ampicillin $(50 \mu \mathrm{g}$ $\mathrm{ml}^{-1}$ ). Cells were pelleted by centrifugation, washed twice with PBS, $\mathrm{pH} 7 \cdot 2$, and resuspended in one-tenth the original volume of PBS, $\mathrm{pH} 7 \cdot 2$. The final cellular concentration of each suspension, measured as $\mathrm{OD}_{600}$, was made equivalent by the addition of PBS. Broth-grown Eik. corrodens cells were similarly washed with PBS, pH 7.2, and the concentration of the suspension adjusted to an $\mathrm{OD}_{600}$ of approximately 0.5. Fresh human erythrocytes from a single donor were washed several times with PBS, $\mathrm{pH} 7 \cdot 2$, once with PBS, pH $5 \cdot 8$, and resuspended to a concentration of $20 \%(\mathrm{w} / \mathrm{v})$ in PBS, pH $5 \cdot 8$. Neuraminidase type $\mathrm{V}$ from Clostridium perfringens (Sigma) was added to a concentration of $1 \mathrm{U} \mathrm{ml}^{-1}$ and the mixture was allowed to incubate for $1 \mathrm{~h} \mathrm{at} 37^{\circ} \mathrm{C}$ with gentle agitation. The erythrocytes were then washed several times with PBS, pH 7.2, and resuspended in the same buffer at a concentration of $1 \%(\mathrm{w} / \mathrm{v})$. The bacterial cell suspensions were diluted in a twofold series in PBS, pH 7.2, across the microtitre plate, leaving $0.05 \mathrm{ml}$ in each well. An equal volume ( $0.05 \mathrm{ml})$ of washed, neuraminidase-treated erythrocytes was added to each well and gently mixed with the bacterial cells. The plates were stored for $12-14 \mathrm{~h}$ at $4{ }^{\circ} \mathrm{C}$ and then examined for evidence of haemagglutination.

Restriction mapping and subcloning. CsCl-gradient-purified plasmid DNA was used for all mapping experiments so as to ensure consistent and efficient digestion by restriction enzymes. Enzyme reactions were carried out under conditions recommended by the manufacturer so as to allow complete digestion and the products were analysed by agarose gel electrophoresis using standard methods (Sambrook et al., 1989). For subcloning, vector DNA was digested with the appropriate restriction enzyme(s) and purified by $0.7 \%$ agarose gel electrophoresis followed by isolation of the desired fragment from the gel using standard techniques (Silhavy et al., 1984). Fragments to be cloned were likewise purified by electrophoresis prior to ligation. Fragments with asymmetric terminal restriction-enzyme-generated ends were subcloned in either pUC18 or pUC19 so as to maintain the original orientation of the fragment with respect to the plasmid-based promoter.

Maxicell analysis. Maxicell analysis of clones and subclones was performed using the method of Sancar et al. (1979) as described by
Silhavy et al. (1984). Following SDS-PAGE (12.5\% separating gel) the proteins in the gel were fixed by treatment for $30 \mathrm{~min}$ in 2propanol/water/acetic acid $(25: 65: 10$, by vol.). The gel was then soaked for $30 \mathrm{~min}$ in the fluorographic reagent Amplify (Amersham) prior to drying using a slab gel dryer (Bio-Rad). The dried gel was then subjected to autoradiography using Kodak XAR- 5 film at $-70^{\circ} \mathrm{C}$ for 12-14 h.

Southern hybridization. DNA samples to be analysed were digested and subjected to electrophoresis in a $1.0 \%(\mathrm{w} / \mathrm{v})$ agarose gel. The DNA was transferred to nylon membranes (Sigma) by the capillary alkaline transfer method (Reed \& Mann, 1985). ${ }^{32} \mathrm{P}$-labelled probe was prepared from gel-electrophoresis-purified fragments using the Multiprime DNA Labelling Kit (Amersham) and $\left[\alpha-{ }^{32}\right.$ P]dCTP (Amersham) according to the directions of the manufacturer. Hybridization was carried out according to the method of Hardy et al. (1985) at $65^{\circ} \mathrm{C}$ in the presence of $10 \%(w / v)$ dextran sulphate (Sigma) and $1 \%(w / v)$ SDS for $18 \mathrm{~h}$ using the POR800 Hybridization Chamber (Hoeffer Scientific Instruments). The membrane was subjected to a wash of low stringency ( $2 \times$ SSPE, $1 \%$ SDS) for $60 \mathrm{~min}$ at $65^{\circ} \mathrm{C}$ followed by a high-stringency wash $(0.1 \times$ SSPE and $1 \%$ SDS $)$ for $15 \mathrm{~min}$ at $65^{\circ} \mathrm{C}$. $(1 \times$ SSPE is $150 \mathrm{~mm}-\mathrm{NaCl}, 10 \mathrm{~mm}$-sodium phosphate, $1 \mathrm{~mm}$-EDTA, pH 7.4.) The membrane was subjected to autoradiography for $6-12 \mathrm{~h}$ at $-70^{\circ} \mathrm{C}$ using a Lightning Plus intensifying screen (DuPont) and Kodak XAR5 film.

DNA sequencing. Fragments to be sequenced were cloned in either pUC19 or pUC18 and the recombinant plasmids purified by centrifugation twice in a gradient of $\mathrm{CsCl}$. Double-stranded sequencing was carried out by the University of Florida DNA Core Sequencing Facility using a modification of the dideoxy chain-termination method of Sanger et al. (1977), incorporating fluorescently tagged dideoxy nucleotides as described by Prober et al. (1987). Fluorescent sequencing fragments generated by the Sequenase enzyme were resolved by PAGE and the gels then scanned by the Genesis 2000 detector system (Dupont Biotechnology Systems). Where necessary, oligonucleotides 17 bases in length were synthesized by the University of Florida DNA Core Synthesis Facility and used as a primer in sequencing reactions. Sequence data were compiled and analysed using programs in the Genetics Computer Group Sequence Analysis Software Package version 6.2 (Devereux et al., 1984).

\section{Results}

Construction of a genomic library and identification of antigen-expressing clones

Approximately 1400 E. coli transformants containing recombinant plasmids were picked and screened for expression of Eik. corrodens antigens using a colony immunoblotting method. In this manner, 22 clones were found to cross-react reproducibly with polyclonal antisera raised in rabbits against Eik. corrodens. E. coli containing the vector pUC9 exhibited no reaction with the antiserum in this assay. In all but three cases, whole cells of the transformants gave a reaction equivalent to that seen with chloroform-lysed cells, suggesting that in all except these clones, the cloned antigen is expressed on the surface of $E$. coli. Preliminary restriction analysis of recombinant plasmids isolated from each of these clones revealed that the majority harboured single-fragment inserts ranging in size from 1.9 to $6.2 \mathrm{~kb}$. Several clones 

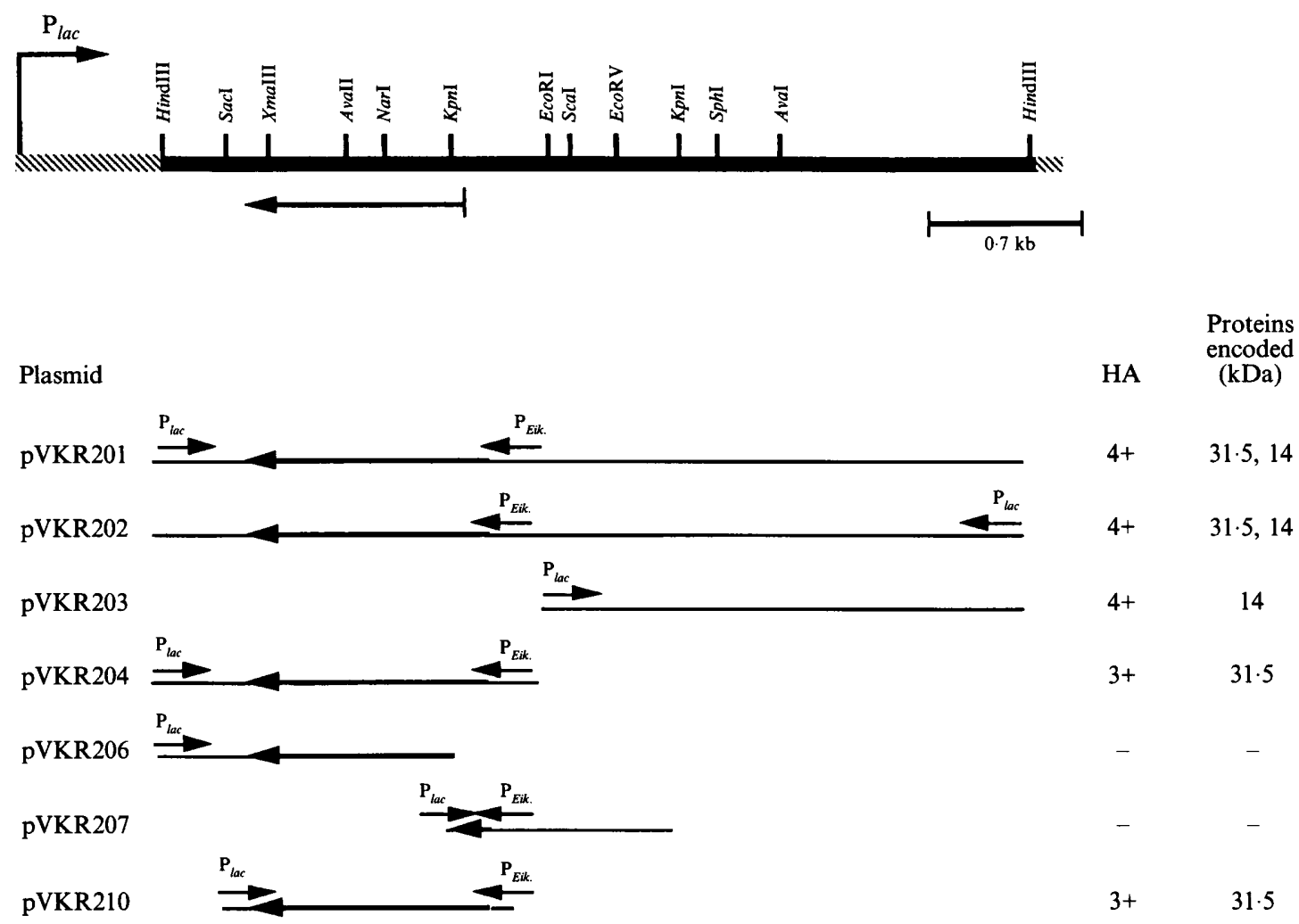

Fig. 1. Localization of the haemagglutinin gene of pVKR201. The restriction map of the insert of pVKR201 and the relative positions of various subclones are shown. The large arrow indicates the position of the open reading frame. Small arrows denote the position and direction of transcription from the plasmid lac promoter as well as the putative Eikenella promoter found on this fragment. Sizes of plasmid-encoded proteins $(\mathrm{kDa})$ are as determined by SDS-PAGE analysis of $\left[{ }^{35}\right.$ S $]$ methionine-labelled maxicells. HA, haemagglutination activity.

contained multiple HindIII fragments of Eik. corrodens DNA.

\section{Identification of two haemagglutinating clones}

Because bacterial adhesins (haemagglutinins) are frequently major surface antigens, we tested each of the antigen-expressing clones in a standard haemagglutination assay using neuraminidase-treated human erythrocytes. In this manner, two clones were found which could agglutinate erythrocytes, while $E$. coli JM 109 harbouring pUC9 possessed no such activity. To confirm this activity, the plasmid DNA was isolated from each clone and used to transform fresh cultures of $E$. coli JM109. In each case $5 / 5$ of the new transformants tested possessed haemagglutination activity equivalent to that of the original clone, confirming that the activity is conferred on $E$. coli by the cloned Eik. corrodens DNA. Clone 1 harboured plasmid pVKR201, which contains a single $3.6 \mathrm{~kb}$ HindIII fragment. Clone 2 harboured plasmid pVKR301, which contains a single $3.2 \mathrm{~kb}$ HindIII fragment. By digestion with a variety of restriction enzymes, both alone and in combination, restriction maps of pVKR201 and pVKR301 were deduced; these are shown in the top portions of Figs 1 and 2 respectively. Comparison of the two restriction maps failed to reveal any obvious similarities between the two cloned DNA fragments. To investigate the regulation of expression of these genes in $E$. coli, we ligated the inserts of pVKR201 and pVKR301 into pUC19 in the reverse orientation, thereby producing pVKR202 and pVKR302 respectively. Transformants harbouring pVKR202 exhibited haemagglutination activity equivalent to the original clone. In contrast, pVKR302 was unable to confer haemagglutination activity on $E$. coli JM109 (Figs 1 and 2).

\section{Southern hybridization}

Southern hybridization analysis was used in order to assess subtle relationships, if any, between the two cloned fragments. The insert from pVKR201 was purified by agarose gel electrophoresis, labelled with ${ }^{32} \mathrm{P}$, and used as a probe in a standard Southern hybridization experiment. As shown in Fig. 3, under the highstringency conditions used, there was no detectable homology to any DNA fragment from $E$. coli JM109 chromosomal DNA or to the insert from plasmid 

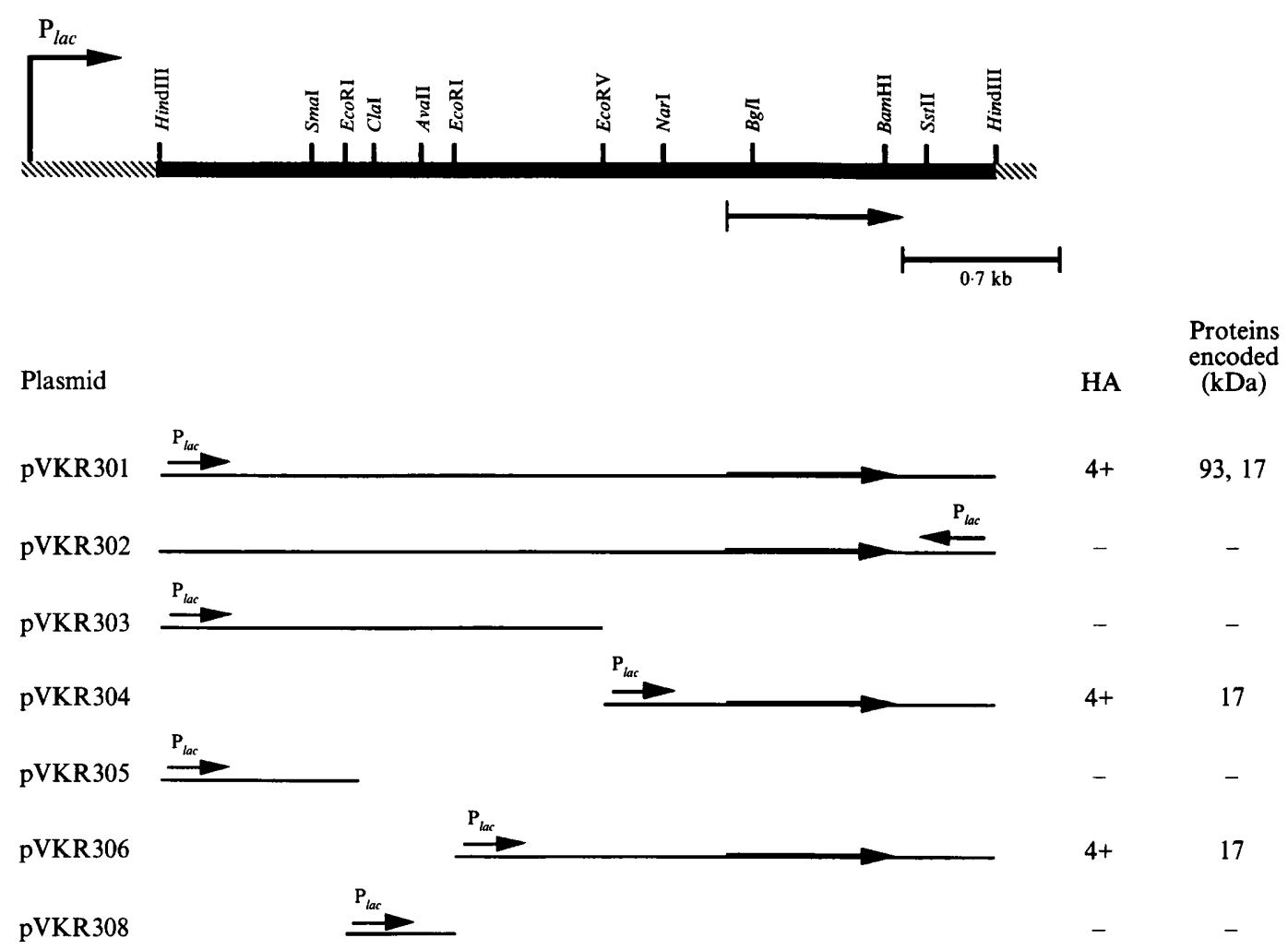

Fig. 2. Localization of the haemagglutinin gene of pVKR301. The restriction map of the insert of pVKR301 and the relative positions of various subclones are shown. The large arrow indicates the position of the open reading frame. Small arrows denote the position and direction of transcription from the plasmid lac promoter. Other details as for Fig. 1.

(a)

$\begin{array}{llllll}1 & 2 & 3 & 4 & 5 & 6\end{array}$

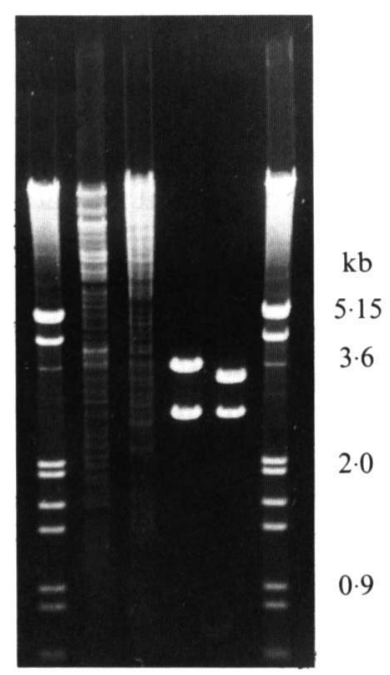

(b) $\begin{array}{llllll}1 & 2 & 3 & 4 & 5 & 6\end{array}$

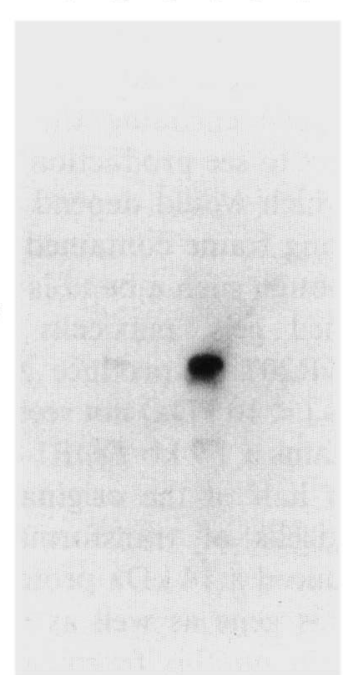

Fig. 3. Southern hybridization analysis of the two haemagglutinin clones from Eik. corrodens. The $3.6 \mathrm{~kb}$ insert of pVKR201 was used as the probe. Both the agarose gel $(a)$ and the corresponding autoradiograph $(b)$ are shown. Lanes: 1 and $6, \lambda$ DNA cut with HindIII and EcoRI; 2, Eik. corrodens ATCC 23834 chromosomal DNA cut with HindIII; 3, E. coli JM109 chromosomal DNA cut with HindIII; 4, pVKR201 isolated from E. coli clone 1 digested with HindIII; 5, pVKR301 isolated from E. coli clone 2 digested with HindIII.

pVKR301. There was a $3.6 \mathrm{~kb}$ hybridizing band in the lane containing HindIII-digested chromosomal DNA from $E$. corrodens (Fig. 3, lane 2), thereby confirming the origin of the cloned fragment. These data indicated that there was no sequence similarity between the two cloned haemagglutinin genes.

\section{Maxicell analysis}

In order to identify the proteins encoded by these fragments, we used the maxicell technique to selectively label plasmid-encoded proteins. As shown in Fig. 4, lane 3 , pVKR201 encodes three proteins which are expressed in E. coli. Proteins A and B migrate very close together and each has a molecular mass of approximately $14 \mathrm{kDa}$ as estimated by SDS-PAGE. Protein C is significantly larger, with an estimated molecular mass of $31.5 \mathrm{kDa}$. Interestingly, this protein is visible as a very intense band in Coomassie-blue-stained SDS-PAGE gels of lysates of clone 1 , while proteins $A$ and $B$ are not clearly visible in such gels (data not shown). In contrast, pVKR301 encodes two proteins not seen in E. coli containing pUC9 alone (Fig. 4, lane 4). Protein 1 has a molecular mass of $93 \mathrm{kDa}$ as estimated by SDS-PAGE, while protein 2 has a molecular mass of $17 \mathrm{kDa}$. Neither of these proteins 


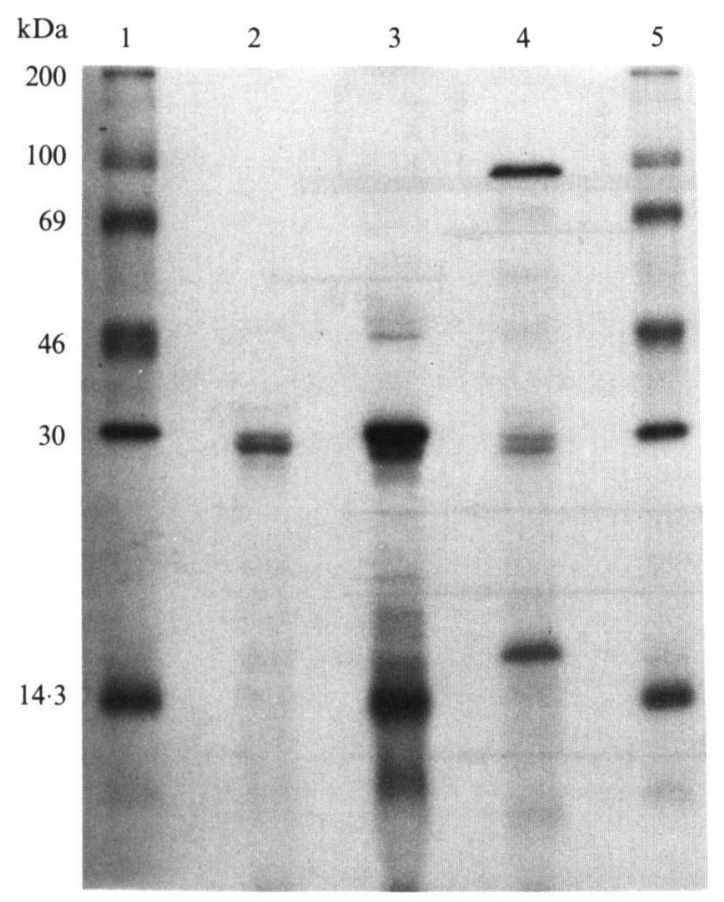

Fig. 4. Maxicell analysis of the two haemagglutinin clones from Eik. corrodens. Maxicells of each E. coli culture were produced by irradiation with an appropriate dose of UV light and labelled using $\left[{ }^{35}\right.$ S $]$ methionine. Labelled proteins were analysed by SDS-PAGE followed by autoradiography. Lanes: 1 and 5 , molecular mass standards; 2, E. coli JM109(pUC9); 3, E. coli JM109(pVKR201); 4, E. coli JM109(pVKR301).

could be visualized on Coomassie-blue stained SDSPAGE gels of lysates of clone 2 (data not shown). Maxicell analysis of $E$. coli harbouring pVKR202 revealed the production of identical proteins to those seen with pVKR201, suggesting that all three proteins are expressed in E. coli under the control of an Eikenella promoter(s) (Fig. 1). As was suggested by the haemagglutination data, maxicells of E. coli harbouring pVKR302 produced no proteins other than those seen with pUC19 alone (Fig. 2), indicating that the genes on the insert of pVKR301 are expressed using the plasmid lac promoter.

\section{Localization of the haemagglutinin gene of clone 1}

In order to identify and localize the haemagglutinin gene carried on the insert of pVKR201, the haemagglutination pattern of a series of subclones (Table 1) was determined. Fragments were cloned into appropriate sites in either pUC18 or pUC19 so as to maintain the orientation, with respect to the plasmid promoter, in which the fragment is found in the original clone. Each subclone was tested in the haemagglutination assay and analysed by the maxicell technique. These data, and the relative positions of each subcloned fragment in the original clone, are shown schematically in Fig. 1. pVKR204, containing a $1.7 \mathrm{~kb}$ HindIII-EcoRI fragment from the lefthand portion of the insert, as depicted in Fig. 1, conferred haemagglutination activity on $E$. coli JM109, and also directed the production of a $31.5 \mathrm{kDa}$ protein as visualized both by Coomassie-blue-stained SDS-PAGE gels of lysates and by maxicells harbouring this plasmid. In contrast, transformants containing plasmid pVKR206, obtained by deletion of the terminal $K p n I-E c o$ RI fragment $(0.5 \mathrm{~kb})$ from pVKR204, were unable to agglutinate erythrocytes. Moreover, transformants harbouring pVKR206 produced no proteins other than those seen with pUC19 alone as visualized by maxicell analysis. These data suggested that the $31.5 \mathrm{kDa}$ protein is the cloned haemagglutinin and that DNA contained in the KpnI-EcoRI fragment is required for activity of the haemagglutinin. This fragment, however, is not sufficient for activity since pVKR207, which contains a $0.7 \mathrm{~kb} K p n I-K p n I$ fragment that includes the KpnI-EcoRI fragment, does not confer haemagglutination activity on $E$. coli. Since the orientation of the fragments in the original clone was preserved in the subclones, the data further suggest that transcription occurs in a direction opposite to that from the plasmid lac promoter. If transcription were to occur in phase with the lac promoter, deletion of the $K p n I-E c o$ RI fragment would represent deletion of the 3' end of the gene. One would therefore expect to obtain a fusion (which may or may not be functional) with the $\beta$ galactosidase gene just downstream of the polylinker of pUC19. No such protein is apparently encoded by pVKR206. Along the same lines, since pVKR207 should contain the $5^{\prime}$ end and upstream regulatory elements of the gene encoding the $31.5 \mathrm{kDa}$ protein, one would expect to see production of a truncated protein, the size of which would depend upon the amount of the open reading frame contained on the KpnI-EcoRI fragment. Although such a band is not visible on Coomassie-bluestained gels, maxicells of transformants harbouring pVKR207 do produce a faint band of low molecular mass $(<10 \mathrm{kDa})$ not seen with pUC19 alone. pVKR203 contains a $1.9 \mathrm{~kb}$ EcoRI-HindIII insert representing the right half of the original insert as depicted in Fig. 1. Maxicells of transformants harbouring this plasmid produced a $14 \mathrm{kDa}$ protein. A detailed characterization of this gene as well as that encoding the third cloned protein on this fragment is reported in the following paper (Rao \& Progulske-Fox, 1993).

\section{Localization of the haemagglutinin gene of clone 2}

As with clone 1, a series of subclones of clone 2 was constructed (see Table 1) and tested for haemagglutination activity and studied by maxicell analysis in order 


\begin{abstract}
EcoRI

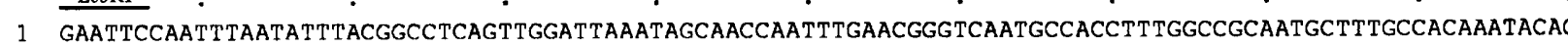

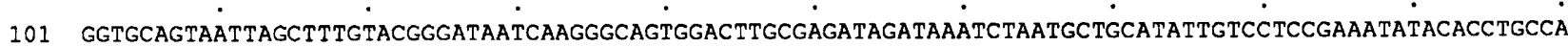

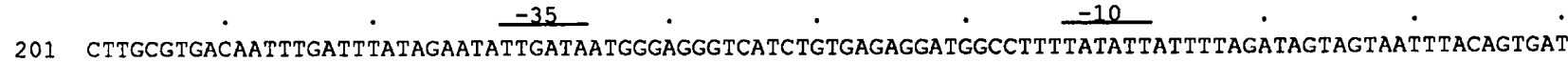

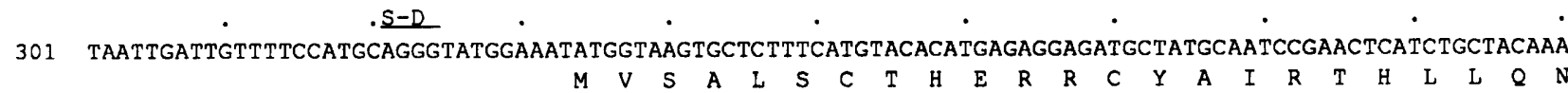

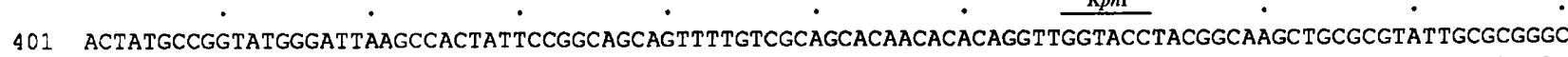
$\begin{array}{llllllllllllllllllllllllllllllllllll}Y & A & G & M & G & L & S & H & Y & S & G & S & S & F & V & A & A & Q & H & T & G & W & Y & L & R & Q & A & A & R & I & A & R & A\end{array}$

501 GGCTGAAGTTTTTGAATTGCAGGAAGACGGTACGGTGCTGGCGGAGCATATTTTGCAGCCGGATTCCGGTGTGTGGACGCTTTATCCACAGGCTCAACAC $\begin{array}{llllllllllllllllllllllllllllllllllll}\text { A } & E & V & F & \text { E } & \text { L } & Q & \text { E } & \text { D } & G & \text { T } & \text { V } & \text { L } & \text { A } & \text { E } & \text { H } & \text { I } & \text { L } & Q & \text { P } & \text { D } & \text { S } & G & V & \text { W } & \text { T } & \text { L } & \text { Y } & \text { P } & \mathcal{Q} & A & Q & H\end{array}$

601 AAGGTGGAGCCGTTGGATGATGATTTTGCCGTGCAGCTGGAATTTCATTGCGAAAAAGCAGATTATTTCCACAAAAAACACGGCATGACTACCACCCATT $\begin{array}{lllllllllllllllllllllllllllllllllll}K & V & E & P & L & D & D & D & F & A & V & Q & L & E & F & H & C & E & K & A & D & Y & F & H & K & K & H & G & M & T & T & T & H & S\end{array}$

701 CCGCCATCCGCGAGGCGGTGCAAACCGTGGCGCCGTGTAAGACCTTGGATTTGGGCTGTGGGCAGGGGCACAATGCGCTGTTTTTGAGCTTGGCCGGATA $\begin{array}{lllllllllllllllllllllllllllllllllllll}\text { A } & I & R & E & A & V & Q & T & V & A & P & C & K & T & \text { L } & \text { D } & \text { L } & G & C & G & \mathcal{C} & G & H & N & A & \text { L } & F & \text { L } & S & \text { L } & A & G & Y\end{array}$ 801 TGATGTGCGCGCTGTGGACCACAGCCCGGCGGCAGTGGCTTCGGTGCTGGATATGGCTGCACGCGAACAGTTGCCGCTGCGGGCGGATGCTTACGATATT $\begin{array}{lllllllllllllllllllllllllllllllllll}D & V & R & A & V & D & H & S & P & A & A & V & A & S & V & \text { L } & D & M & A & A & R & E & Q & \text { L } & \text { P } & \text { L } & \text { R } & \text { A } & \text { D } & \text { A } & Y & D & I\end{array}$

901 AACGCTGCTGCTTTGAATGAAGATTACGATTTTATCTTTGCCACGgTAGTGTTTATATTCCTCCAGGCAGGCCGTGTGCCGGAGATTATTGCCGATATGC $\begin{array}{llllllllllllllllllllllllllllllllll}N & A & A & A & L & N & E & D & Y & D & F & I & F & A & T & V & V & F & I & F & L & Q & A & G & R & V & P & E & I & I & A & D & M & Q\end{array}$ 1001 AGgCGCATACTCGGCCTGGTGGCTATAACTTGATCGTGTCGGCAATGGATACAGCAGACTACCCCTGTCATATGCCGTTTTCGTTCACATTCAAAGAAGA $\begin{array}{llllllllllllllllllllllllllllllllllll}A & \mathrm{H} & \mathrm{T} & \mathrm{R} & \mathrm{P} & \mathrm{G} & G & \mathrm{Y} & \mathrm{N} & \mathrm{L} & \mathrm{I} & \mathrm{V} & \mathrm{S} & \mathrm{A} & \mathrm{M} & \mathrm{D} & \mathrm{T} & \mathrm{A} & \mathrm{D} & \mathrm{Y} & \mathrm{P} & \mathrm{C} & \mathrm{H} & \mathrm{M} & \mathrm{P} & \mathrm{F} & \mathrm{S} & \mathrm{F} & \mathrm{T} & \mathrm{F} & \mathrm{K} & \mathrm{E} & \mathrm{D}\end{array}$ 101 CGAGCTGCGGCAGTATTATGCCGACTGGGAATTGTTGAAATACGAAGAAGCCGTGGGCTTGATGCACGCTACTGATGCGCAAGGGCGGCCGATTCAATTG $\begin{array}{lllllllllllllllllllllllllllllllllll}E & L & R & Q & Y & Y & A & D & W & E & L & L & K & Y & E & E & A & V & G & L & M & H & A & T & D & A & Q & G & R & P & I & Q & L\end{array}$

1201 AAATTTGTGACGATGTTGGCGAAGAAGCCCGGCTAAACTATTCGTATTGTATGAAAAAGGCTGCCTGAAAACTTTCAGGTAGCCTTCTTTTATGTTCGCG K

1301 CGGCAACTAGCCGGACTTACTCTTTCGCAAGTATCTGCCCGCCTCCGGCTCTTTCGCATTGAGAAAACCGCCTCTTTGGTGTGCCCACAGGCTGGCGTAG

1401 AGGCCGCCCTTGGCTAAGAGCTCGGCGTGGTTGCCTTCTTCCACGATGCGGCCTTTATCGAGCACGATGAGGCGATCCATGGCGGCGGTGGTGGAGAGCC

1501 GGTGGGCGATGGCAATAACGGTTTTGCCTTCCATCATGGTATCGAGGCTTTCTTGGATGGCGGCTTCCACTTCGGAATCGAGCGCGCTGGTGGCTTCATC

1601 TAAAAGCAGAATCGGTGCGTCTTTGAGCATCACTTGTGCGATAGGGATGCGCTGGCGCTGGCCGCCGGAAAGCTT
\end{abstract}

Fig. 5. Nucleotide sequence of the 1675 bp insert of pVKR204 containing the gene for a $31.5 \mathrm{kDa}$ haemagglutinin from Eik. corrodens. The deduced amino acid sequence is shown below the nucleotide sequence. Potential -35 and -10 promoter sequences as well as a potential ribosome-binding site (S-D) are indicated above the sequence. Lines above the sequence denote inverted repeats which may function in transcription termination.

to localize the haemagglutinin gene on the cloned fragment. Once again, fragments were subcloned in either pUC19 or pUC18 so as to maintain their original orientation. Orientation was a particularly important factor in the case of clone 2 because of our earlier results which suggested that expression was dependent upon promoter sequences in the vector. These data, along with the relative positions of each subcloned fragment on the original insert are shown schematically in Fig. 2 . Transformants containing pVKR306, which harbours a $2.4 \mathrm{~kb} E c o \mathrm{RI}-H i n \mathrm{dIII}$ fragment from the right side of the insert as depicted in Fig. 2, were capable of haemagglutination. In addition, maxicells prepared from these transformants directed the production of a $17 \mathrm{kDa}$ protein. Deletion of a terminal $1.0 \mathrm{~kb} E c o \mathrm{RI}-E c o \mathrm{RV}$ fragment from the insert of pVKR306 produced plasmid
pVKR304. Transformants containing this plasmid were also able to agglutinate erythrocytes and produced the $17 \mathrm{kDa}$ protein, as determined with maxicells. Plasmids pVKR303, 305 and 308, containing inserts from various portions of the left side of the insert, were all unable to confer haemagglutination activity on $E$. coli and directed the production of no proteins other than those seen with pUC19 alone. These data suggested that the $17 \mathrm{kDa}$ protein is the cloned haemagglutinin and that the gene encoding this protein is located within the $1.4 \mathrm{~kb}$ EcoRV-HindIII fragment. Since expression of both proteins appears to be under the control of the lac promoter, the two genes must be transcribed from left to right as drawn in Fig. 2. The gene encoding the $93 \mathrm{kDa}$ protein must be located to the left of the haemagglutinin gene since there is insufficient DNA within the $1.4 \mathrm{~kb}$ 
EcoRV-HindIII fragment to encode both proteins. Production of a C-terminal fusion protein is likewise unlikely since the $93 \mathrm{kDa}$ protein is not seen with either pVKR306 or pVKR304. A detailed characterization of the $93 \mathrm{kDa}$ protein will be reported elsewhere.

\section{Nucleotide sequence of the haemagglutinin gene from clone 1}

The complete nucleotide sequence of the $1.7 \mathrm{~kb}$ insert of pVKR204 found to contain the haemagglutinin gene (Table 1) was determined and is shown in Fig. 5. The $\mathrm{G}+\mathrm{C}$ content of this fragment was $50.4 \mathrm{~mol} \%$, which agrees well with that previously reported (54-56 mol \%) for the chromosome of Eik. corrodens (Jackson \& Goodman, 1984). We identified a major open reading frame (ORF) on this fragment beginning at position 334 and extending 903 nucleotides to position 1237. Transcription occurs in a direction opposite to that of the lac promoter, as suggested by the experimental data and as diagrammed in Fig. 1. The protein encoded by this ORF is composed of 300 amino acid residues and has a deduced molecular mass of $33.5 \mathrm{kDa}$. This value is consistent with that $(31.5 \mathrm{kDa})$ observed by SDS-PAGE and maxicell analysis (Fig. 4). The proposed translation start site is preceded by a potential ribosome-binding site, AGGG, at positions -10 to -13 (Gold et al., 1981). From the subcloning data presented above, it was clear that the Eikenella promoter which regulates expression of the haemagglutinin genes is included in the cloned fragment and that this promoter is functional in E. coli. Upon examination of regions of the sequence upstream of the ORF, we found that from position 267 to 272 , there is a hexanucleotide sequence, TATATT, which differs by only a single nucleotide from the consensus sequence, TATAAT, for the Pribnow or TATA box portion of prokaryotic promoters (Rosenberg $\&$ Court, 1979). In addition, from position 229 to 234 , there is a hexanucleotide sequence, TTGATA, which differs by a single nucleotide from the consensus sequence, TTGACA, for the -35 region of prokaryotic promoters (Rosenberg \& Court, 1979). While it is likely that these two regions comprise the promoter of this gene, precise and definitive localization of the upstream regulatory elements will await the results of primer extension and/or DNA footprinting studies. Beginning 17 nucleotides downstream of the TAA termination codon, at position 1253, and extending to position 1290 , is a potential stem-loop structure (lines drawn above sequence in Fig. 5), which may function in termination of transcription (Rosenberg \& Court, 1979). Given these data, we constructed an additional subclone, pVKR210 (Fig. 1) in which a $1.2 \mathrm{~kb}$ Ssp I-Sst I fragment, extending from position 228 to 1418, was ligated to the HincII-SstI sites of pUC18. This subclone contains the entire open reading frame of the haemagglutinin with little flanking DNA other than that implicated in regulation of expression, i.e. putative promoter and termination sequences. In addition, the fragment was ligated in an orientation opposite that of the lac promoter. As expected, transformants harbouring pVKR210 were able to agglutinate erythrocytes. Moreover, large amounts of the $31.5 \mathrm{kDa}$ protein were clearly visible in SDS-PAGE gels of lysates of these transformants. These data provide additional evidence as to the proposed promoter sequences and direction of transcription of the haemagglutinin.

Secreted proteins, including those which ultimately remain associated with the bacterial outer membrane, generally possess a leader sequence consisting of 15-20 hydrophobic amino acids (Inouye \& Halegoua, 1980). Interestingly, the leader resulting from initiation at position 334 as proposed here is remarkably hydrophilic, with $13 / 20$ of the amino acids being polar residues. This potential leader sequence would therefore not be similar to any known signal sequences. Confirmation of the proposed start site and hence the composition of the leader sequence will, of course, require $\mathrm{N}$-terminal sequencing of the protein. Beginning at residue 200 is a hydrophobic stretch where $17 / 21$ of the amino acids are nonpolar. The average hydropathy of this region as determined by the method of Kyte \& Doolittle (1982) is $+1 \cdot 6$, making it consistent with properties of the membrane-spanning region of a protein. Such a stretch could therefore be important in the anchoring of this protein in the outer membrane of the cell. A computer search of the EMBL and GenBank databases failed to reveal any significant relationship between the haemagglutinin of clone 1 and any previously sequenced proteins.

\section{Nucleotide sequence of the haemagglutinin gene from clone 2}

The complete nucleotide sequence of the insert of pVKR304, which was found to contain the haemagglutinin gene, was determined and is shown in Fig. 6. The $\mathrm{G}+\mathrm{C}$ content of this fragment was $50.6 \mathrm{~mol} \%$, which is remarkably close to that found for the insert of pVKR204 containing the haemagglutinin gene from clone 1 . We identified a major ORF on this fragment, beginning at position 489 and extending 639 nucleotides to position 1128. The protein encoded by this ORF is 212 amino acid residues in length with a deduced molecular mass of $23712 \mathrm{Da}$ and isoelectric point of 8.25. The deduced molecular mass compares fairly well with that $(17 \mathrm{kDa})$ obtained by maxicell analysis (Fig. 4). Prior to the start site for translation is a potential Shine--Dalgarno 


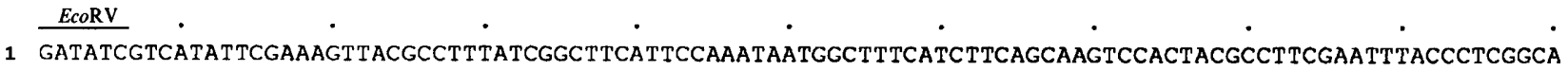

101 CCAACCGGAÁTCACGATTGGCACGGGATTGGCGCGCAGACGGGTTTTCATCTGCTCAACTACGCGGAAGAAGTTGGCACCTTGACGGTCCATTTTGTTTA

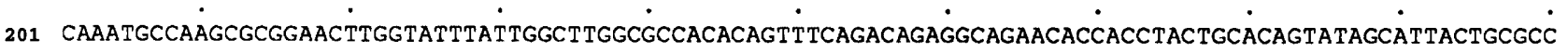

301 GTCCAATACACGCATAGAACGCTCCACCTCTACGGTGAAGTCAACGTGTCCGGgGGTATCAATGATGCTGAAACGgTGCPCAGGAAACTGCTTCGCCATA

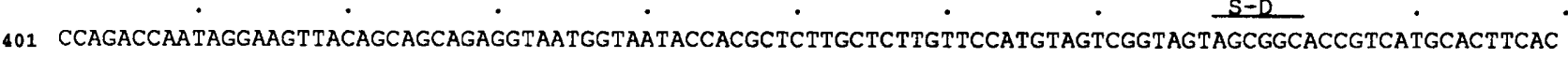

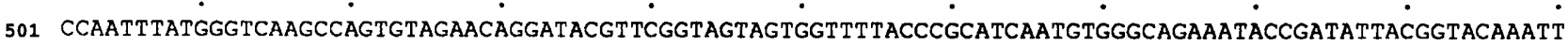

$\begin{array}{llllllllllllllllllllllllllllllllll}Q & F & M & G & Q & A & S & V & E & Q & D & T & F & G & S & S & G & F & T & R & I & N & V & G & R & N & T & D & I & T & V & Q & I\end{array}$

601 AATCGgGGTTTTACGAGCCÁTTTCAATCGCCTTTCAAAATTAGAAGCGGAAGTGAGAGAAGGCTTTGTTGGCTTCAGCCATGCGGTGTACTTCTTCACGT $\begin{array}{llllllllllllllllllllllllllllllllllll}N & R & G & F & T & S & H & F & N & R & L & S & K & L & E & A & E & V & R & E & G & F & V & G & F & S & H & A & V & Y & F & F & T & F\end{array}$ 701 TTtTTCATGGCGCCGCCACGgCCTTCTGCGGCATCAATCAACTCATCGgCCAGgCGCAAÁTCCATGGATTTTTCGCCACGCTTGCGGGCTGCATCGCGCA $\begin{array}{lllllllllllllllllllllllllllllllllllllllll}F & H & G & A & A & T & A & F & C & G & I & N & Q & L & I & G & Q & A & Q & I & H & G & F & F & A & T & L & A & G & C & I & A & H\end{array}$ 801 CCCAGCGCATTGCCAAGGCCAAACGGCGGGAAGGACGAACCTCAACAGGAACCTGGTAGTTAGCACCACCAACACGGCGGCTTTTCACTTCCACGATGGG

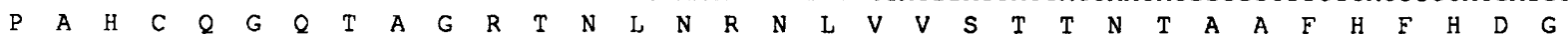
901 TTTGGCATTGTCGATGgCTTCGTTAAACACTTCGATTGCCTCTTTGCCCTGTACTTTCTTGGCAGTTTGCTCCAGAgCACCATACACGATGCGCTCGTCA $\begin{array}{lllllllllllllllllllllllllllllllllllll}F & G & I & V & D & G & F & V & K & H & F & D & C & L & F & A & L & Y & F & L & G & S & L & L & Q & S & T & I & H & D & A & L & V & N\end{array}$ 1001 ACCGATTTTTTACCGTCAACCATCAAGgCATTCATAAACTTGGTCAGTTCAACGCTGCCGAACTTCGGATCCGgCAATACGTCGCGCTTAGgGACTTCTC $\begin{array}{llllllllllllllllllllllllllllllllll}R & F & F & T & V & N & H & Q & G & I & H & K & L & G & Q & F & N & A & A & E & L & R & I & R & Q & Y & V & A & L & R & D & F & S\end{array}$

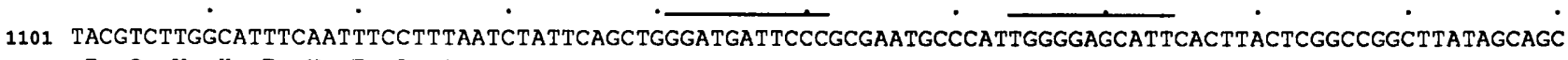
T $\quad S$ W

1201 AATAACGGCCGACGTGCCTGTATTAAAAAATTATTTCGgGCGTTTAGCACCGTATTTGGAGCGTGCCTGTTtGCGgTCTTtTCACGCCGGCAGTATCCAAA 1301 GTTCCACGAACAGTGTGGTAGCGCACACCCGGCAAGTCTTTCACACGACCGCCGCGGATCAGCACCACGCTGTGCTCTTGCAAGTTGTGACCTTCACCGC

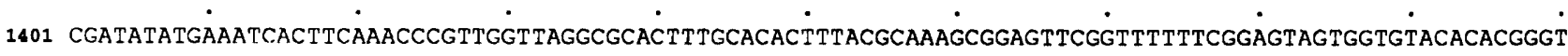
1501 GCATACGCCGCGTTTTTGCGGGCAAGCTT
\end{abstract}

Fig. 6. Nucleotide sequence of the $1531 \mathrm{bp}$ insert of pVKR304 containing the gene for a $17 \mathrm{kDa}$ haemagglutinin from Eik. corrodens. The deduced amino acid sequence is shown below the nucleotide sequence. Lines above the sequence denote inverted repeats which may function in transcription termination.

sequence, AGCGGCA, from position -12 to -6 (Gold et al., 1981). There is a second potential start site beginning at position 510 , which would result in a protein six amino acids shorter. However, this start codon is not preceded by a potential ribosome-binding site. Therefore, translation is more likely to begin at position 489. Experimental evidence appears to indicate that the haemagglutinin of clone 2 is expressed under the control of the plasmid lac promoter. We could identify no sequences with similarity to the consensus sequence for the $E$. coli $\sigma^{70}$ promoter. Downstream of the TAA termination codon are two sequences which can potentially form stem-loop structures. The first occurs at position 1143 and extends to position 1177 . The second begins at position 1206 and extends 41 nucleotides to position 1246. One or both of these structures may function in rho-independent termination of transcription. As with the haemagglutinin of clone 1, examination of the $\mathrm{N}$-terminal sequence of the haemagglutinin as derived from the nucleotide sequence failed to reveal any characteristics similar to known signal peptides. A computer search of the EMBL and GenBank databases (releases through March 1991) failed to reveal any significant relationship between the haemagglutinin of clone 2 and any previously sequenced proteins. Moreover, computer-assisted comparison of the amino acid sequences of the haemagglutinins from clones 1 and 2 failed to reveal any significant regions or domains of homology between the two proteins.

\section{Discussion}

It has been shown previously that Eik. corrodens can agglutinate human erythrocytes, and it has been hypothesized that as with other mucosal pathogens, haemagglutination is strongly correlated with adherence 
(Ebisu \& Okada, 1983). In order to facilitate the study of the haemagglutinin(s) and other putative virulence factors of this fastidious micro-organism, we constructed a library of the chromosomal DNA of Eik. corrodens in E. coli JM109 using the plasmid vector pUC9.

Two clones were identified which could agglutinate erythrocytes. On the basis of different restriction maps, differences in the number and sizes of proteins encoded, and a lack of homology by Southern hybridization, we concluded that two distinct DNA fragments had been cloned and that Eikenella therefore possesses at least two proteins capable of agglutinating erythrocytes. This result was somewhat surprising since previous work (Yamazaki et al., 1988) had indicated that this organism possessed only one such protein. Yamazaki et al. (1988) reported the partial purification of a high-molecularmass haemagglutinating factor from Eik. corrodens. Reduction of this protein preparation, which migrated as a single band in SDS-PAGE, with $\beta$-mercaptoethanol resulted in the production of several protein bands. No details as to the sizes or relative proportions of these smaller proteins were given. It is nevertheless tempting to speculate that the two proteins which we have cloned are subunits of a much larger complex on the Eikenella surface, with two of the proteins observed by Yamazaki et al. (1988) being identical to those described here. Alternatively, these two proteins could occupy completely distinct sites on the bacterial outer membrane and might therefore carry out distinct functions (i.e. have different receptor molecules) in the process of adherence.

In order to characterize the two haemagglutinin genes further, we determined the nucleotide sequences of the two cloned fragments. As suggested by experimental evidence, we could detect no relationship between the two cloned elements at either the nucleotide or amino acid levels. Moreover, these two haemagglutinating proteins both appear to possess novel sequences, as there was no significant similarity between either gene and any previously sequenced proteins in the EMBL and GenBank databases, including haemagglutinins identified in other bacteria.

Experimental evidence suggested that the haemagglutinin gene from clone 1 is expressed under the control of an Eikenella promoter. Sequences immediately upstream of the haemagglutinin gene from clone 1 show striking homology to the consensus sequences for bacterial promoters (Rosenberg \& Court, 1979). Moreover, the translation start site is preceded by a fairly good ribosome-binding site. Taken together, these characteristics would suggest that this protein should be efficiently expressed in $E$. coli. Indeed, this protein is clearly visible as a broad, intense band in Coomassieblue-stained SDS-PAGE gels of lysates of transformants harbouring this gene. It is interesting that a heterologous promoter can direct the production of much higher levels of a protein than are often seen with foreign proteins expressed with an E. coli promoter. For example, the haemagglutinin of clone 2 , which requires the lac promoter for expression, is not visible on Coomassieblue-stained SDS-PAGE gels. Codon usage is also believed to play a role in the level of protein expression (Grosjean \& Fiers, 1982). A number of codons are used infrequently in genes of highly expressed proteins in $E$. coli (Grosjean \& Fiers, 1982), including AUA, CGG, AGA, AGG, CUA, CGA, GGA and GGG. In the gene encoding the haemagglutinin from clone 1 , with the exception of the arginine codon, CGG, each of these codons was the most infrequently used of those available for the particular amino acid. These findings are consistent with a high level of expression in E. coli. In contrast, of the six possible codons encoding arginine, CGG is the one preferentially used (6/14 Arg codons). The use of this codon, which is believed to be an especially minor species in $E$. coli, may be important in the modulation of expression of this protein. However, it is also possible that Eikenella produces significant amounts of the tRNA which recognizes CGG and the use of this codon in this gene may therefore reflect a difference in the distribution of tRNA species between Eikenella and E. coli.

The haemagglutinin gene from clone 2 requires the lac promoter for expression in E. coli. Examination of sequences upstream of this gene failed to reveal regions with clear homology to bacterial promoter consensus sequences. It is likely therefore that the haemagglutinin gene is read as part of a polycistronic message with one or more upstream genes. Because the upstream gene (which encodes a $93 \mathrm{kDa}$ protein) also appears to require the lac promoter for expression, it is possible either that the Eikenella promoter was not included in the cloned fragment or that the promoter cannot be used by the transcriptional apparatus of $E$. coli. The second possibility would indicate that Eikenella possesses more than one class of promoter, only some of which will function in E. coli. Such a scenario is not without precedent. Promoters of the oral pathogen Porphyromonas (Bacteroides) gingivalis appear to be equally heterogeneous with regard to function in $E$. coli (Progulske-Fox et al., 1989). Examination of codon usage in the haemagglutinin gene from clone 2 revealed several important differences from that observed with the haemagglutinin gene from clone 1 . There was no clear bias against the use of the eight rare codons of $E$. coli (Grosjean \& Fiers, 1982). Three of these, CGG, AGA and AGG, are used frequently in this gene. Interestingly, however, in the case of the four threonine codons, in which $\mathrm{A}$ and $\mathrm{C}$ occupy the first two positions, there is a clear preference for $\mathrm{G}$ or $\mathrm{C}$ in the third position $(17 / 17$ 
cases). Similarly, of the four alanine codons, there is a strong bias against the use of GCA (0/19 cases). The significance of this pattern is unclear, but may once again reflect differences between the tRNA content of Eikenella and that of $E$. coli.

In both cases, the $\mathrm{G}+\mathrm{C}$ content of the Eikenella insert was consistent with that determined previously for the chromosome of Eik. corrodens (Jackson \& Goodman, 1984). This suggests that these two genes are either purely of Eikenella origin or were acquired by this species long ago in its evolutionary past. The fact that no homology could be found between these proteins and any others previously sequenced further suggests an Eikenella origin for both of them. However, this lack of homology may also be a reflection of our limited knowledge, at the molecular level, of other Gramnegative anaerobes and facultative aerobes to which Eikenella may be closely related.

It is especially significant that the two proteins described here are functionally expressed (as haemagglutinins) in E. coli, to which Eikenella is not closely related. Surprisingly, upon examination of the amino acid sequences of the two proteins as derived from the nucleotide sequence, we could not detect a pattern consistent with a conventional signal or leader sequence. These proteins must nevertheless be successfully transported to the outer surface of the outer membrane of the cell since they are apparently able to interact effectively with the erythrocyte membrane. The subtle signals encoded in the $\mathrm{N}$-terminus of each protein must therefore be recognized by the $E$. coli machinery involved in the transport and secretion of proteins.

The two genes described in this report represent the first to be cloned and sequenced from the chromosome of Eik. corrodens. In addition to showing that genes from this bacterium can be efficiently expressed in E. coli, these studies will assist in the complete characterization of these unique proteins at the molecular level. Furthermore, by facilitating the construction of selective mutations in each protein, the roles of each in the pathogenic process can be assessed.

This work was supported in part by Public Health Service grant DE07117 from the National Institute for Dental Research and by NIDR BSRG grant RR05728. V.R. is the recipient of NIH predoctoral training grant DE-07200.

The University of Florida DNA Sequencing Core Laboratory was supported by Biomedical Research grant 110246212 from the University of Florida Division of Sponsored Research and the Interdisciplinary Center for Biotechnology Research.

\section{References}

Behling, U. H., Pham, P. H. \& Nowotny, A. (1979). Biological activity of the slime and endotoxin of the periodontopathic organism Eikenella corrodons. Infection and Immunity 26, 580-584.
Brooks, G. F., O’Donoghue, J. M., Rissing, J. P., SoApes, K. \& SMITH, J. W. (1974). Eikenella corrodens, a recently recognized pathogen: infections in medical-surgical patients and in association with methylphenidate abuse. Medicine 53, 325-342.

Cheng, A. F., Man, D. W. K. \& French, G. L. (1988a). Thyroid abscess caused by Eikenella corrodens. Journal of Infection 16, 181-185.

Cheng, A. F., South, J. R. \& French, G. L. (1988b). Eikenella corrodens as a cause of brain abscess. Scandinavian Journal of Infectious Diseases 20, 667-671.

Decker, M. D., Graham, B. S., Hunter, E. B. \& Liebowitz, S. M. (1986). Endocarditis and infections of intravascular devices due to Eikenella corrodens. American Journal of the Medical Sciences 292, 209-212.

DeMello, F. J. \& Leonard, M. S. (1979). Eikenella corrodens: a new pathogen. Oral Surgery 47, 401-404.

DevereuX, J., HaEberLi, P. \& SMithies, O. (1984). A comprehensive set of sequence analysis programs for the vax. Nucleic Acids Research 12, 387-395.

DRAKE, A. F. \& Fischer, J. J. (1986). Eikenella corrodens as a cause of recurrent and persistent infections of the head and neck. American Journal of Otolaryngology 7, 426-430.

Dzink, J. L., Tanner, A. C. R., Haffajee, A. D. \& Socransky, S. S. (1985). Gram-negative species associated with active destructive periodontal lesions. Journal of Clinical Periodontology 12, 648-659. EBISU, S. \& OKaDA, H. (1983). Agglutination of human erythrocytes by Eikenella corrodens. FEMS Microbiology Letters 18, 153-156.

EIKEN, M. (1958). Studies on an anaerobic rod-shaped Gram-negative microorganism: Bacteroides corrodens, n. sp. Acta Pathologica et Microbiologica Scandinavica 43, 404-416.

FarRington, M., EYKYN, S. J., WaLKer, M. \& Warren, R. E. (1983). Vertebral osteomyelitis due to coccobacilli of the HB group. British Medical Journal 287, 1658-1660.

Flesher, S. A. \& BotTone, E. J. (1989). Eikenella corrodens cellulitis and arthritis of the knee. Journal of Clinical Microbiology 27, 2606-2608.

GibBons, R. J. (1989). Bacterial adhesion to oral tissues: a model for infectious diseases. Journal of Dental Research 68, 750-760.

GibBons, R. J. \& HouTE, J. v. (1975). Bacterial adherence in microbial ecology. Annual Review of Microbiology 29, 19-44.

Gold, L., Pribnow, D., Schneider, T., Shinedling, S., SwebiliusSinger, B. \& STORMO, G. (1981). Translational initiation in prokaryotes. Annual Review of Microbiology 35, 365-403.

Grosjean, H. \& Fiers, W. (1982). Preferential codon usage in prokaryotic genes: the optimal codon-anticodon interaction energy and the selective codon usage in efficiently expressed genes. Gene 18, 199-209.

Hardy, K., Peterlin, B., Atchison, R. \& Stobo, J. (1985). Regulation of expression of the human interferon gamma gene. Proceedings of the National Academy of Sciences of the United States of America 82, 8173-8177.

HENRIKSEN, S. (1948). Studies in Gram-negative anaerobes II: Gramnegative anaerobic rods with spreading colonies. Acta Pathologica et Microbiologica Scandinavica 25, 368-375.

HeNRIKSEN, S. D. (1969). Corroding bacteria from the respiratory tract. II. Bacteroides corrodens. Acta Pathologica et Microbiologica Scandinavica 75, 91-96.

HoFSTAD, T. \& HoRN, A. (1989). Isolation of Eikenella corrodens from a liver abscess. Acta Chirurgica Scandinavica 155, 139-140.

Inouye, M. \& Halegoua, S. (1980). Secretion and membrane localization of proteins in Escherichia coli. Critical Reviews in Biochemistry 7, 339-371.

IsH-Horowicz, D. \& BURKE, J. (1981) Rapid and efficient cosmid cloning. Nucleic Acids Research 9, 2989-2998.

JACKSON, F. L. \& GoODMAN, Y. E. (1984). Genus Eikenella. In Bergey's Manual of Systematic Bacteriology, vol. 1, pp. 597-600. Edited by N. R. Krieg \& J. G. Holt. Baltimore: Williams and Wilkins.

JONES, G. W. \& FRETER, R. (1976). Adhesive properties of Vibrio cholerae: nature of the interaction with isolated rabbit brush border membranes and human erythrocytes. Infection and Immunity 14, 240-245.

Jones, G. W. \& Richardson, L. A. (1981). The attachment to, and 
invasion of HeLa cells by Salmonella typhimurium: the contribution of mannose-sensitive and mannose-resistant haemagglutinating activities. Journal of General Microbiology 127, 361-370.

JoNEs, J. L. \& RoMIG, D. A. (1979). Eikenella corrodens: a pathogen in head and neck infections. Oral Surgery 48, 501-505.

KYTE, J. \& DoolitTle, R. F. (1982). A simple method for displaying the hydropathic character of a protein. Journal of Molecular Biology 157, 105-132.

Labigne-Roussel, A., Schmidt, M. A., Walz, W. \& Falkow, S. (1985). Genetic organization of the afimbrial adhesin operon and nucleotide sequence from a uropathogenic Escherichia coli gene encoding an afimbrial adhesin. Journal of Bacteriology 162, $1285-1292$.

LANDIS, S. J. \& KoRVER, J. (1983). Eikenella corrodens endocarditis: case report and review of the literature. Canadian Medical Association Journal 128, 822-824.

Listgarten, M. A., Johnson, D., Nowotny, A., TANnER, A. C. R. \& SoCRANSKY, S. S. (1978). Histopathology of periodontal disease in gnotobiotic rats monoinfected with Eikenella corrodens. Journal of Periodontal Research 13, 134-148.

Lobet, Y., Peacock, M. G. \& Cieplak, W. J. (1989). Frame-shift mutation in the lac $Z$ of certain commercially available pUC18 plasmids. Nucleic Acids Research 17, 4897.

MASSEY, B. T. (1989). Eikenella corrodens isolated from a polymicrobial hepatic abscess. American Journal of Gastroenterology 84, 1100-1102.

Mattison, G. D., Haddix, J. E., Kehoe, J. C. \& Progulske-Fox, A. (1987). The effect of Eikenella corrodens endotoxin on periapical bone. Journal of Endodontics 13, 559-565.

MiKı, Y., EBISU, S. \& OKADA, H. (1986). The adherence of Eikenella corrodens to guinea pig macrophages in the absence and presence of anti-bacterial antibodies. Journal of Periodontal Research 22, 359-365.

Prober, J. M., Trainor, G. L., Dam, R. J., Hobbs, F. W., Robertson, C. W., Zagursky, R. J., Cocuzza, A. J., Jensen, M. A. \& BAuMEISTER, K. (1987). A system for rapid DNA sequencing with fluorescent chain-terminating dideoxynucleotides. Science $\mathbf{2 3 8}$, 336-341.

Progulske, A. \& Holt, S. C. (1987). Studies on the growth of Eikenella corrodens 23834. Oral Microbiology and Immunology 2, $2-9$.

Progulske, A., Mishell, R., Trummel, C. \& Holt, S. C. (1984). Biological activities of the outer membrane and lipopolysaccharide from Eikenella corrodens. Infection and immunity 43, 178-182.

Progulske-Fox, A., Tumwasorn, S. \& Holt, S. C. (1989). The expression and function of a Bacteroides gingivalis hemagglutinin gene in Escherichia coli. Oral Microbiology and Immunology 4, 121-131.
RaO, V. K. \& Progulske-Fox, A. (1993). Cloning and sequencing of two type 4 ( $N$-methylphenylalanine) pilin genes from Eikenella corrodens. Journal of General Microbiology 139, 651-660.

REED, K. C. \& MANN, D. A. (1985). Rapid transfer of DNA from agarose gels to nylon membranes. Nucleic Acids Research 13, 7207-7221.

ROSENBERG, M. \& COURT, D. (1979). Regulatory sequences involved in the promotion and termination of RNA transcription. Annual Review of Genetics 13, 319-353.

Sambrook, J., Fritsch, E. F. \& Maniatis, T. (1989). Molecular Cloning: a Laboratory Manual, 2nd edn. Cold Spring Harbor, NY: Cold Spring Harbor Laboratory.

SANCAR, A., HaCK, A. M. \& RuPP, W. D. (1979). Simple method for identification of plasmid-encoded proteins. Journal of Bacteriology 137, 692-693.

Sanger, F., Nicklen, S. \& Coulson, A. R. (1977). DNA sequencing with chain terminating inhibitors. Proceedings of the National Academy of Sciences of the United States of America 74, 5463-5467.

SChmidt, D. R. \& Herkman, J. D. (1983). Eikenella corrodens in human bite infections of the hand. Journal of Trauma 23, 478-482.

Silhavy, T., Berman, T. \& ENQUIST, L. (1984). Experiments with Gene Fusions. Cold Spring Harbor, NY: Cold Spring Harbor Laboratory.

Sobel, J. D., Carrizosa, J., Ziobrowski, T. F. \& Gluckman, S. J. (1981). Polymicrobial endocarditis involving Eikenella corrodens. American Journal of the Medical Sciences 282, 41-44.

Sporken, J. M. J., MuYTJens, H. L. \& Vemer, H. M. (1985). Intrauterine infection due to Eikenella corrodens. Acta Obstetrica et Gynaecologica Scandinavica 64, 683-684.

Stoloff, A. L. \& Gillies, M. L. (1986). Infections with Eikenella corrodens in a general hospital: a report of 33 cases. Reviews of Infectious Diseases 8, 50-53.

Tanner, A. C. R., Haffer, C., Bratthal, G. T., Visconti, R. A. \& SoCRANSKY, S. S. (1979). A study of the bacteria associated with advancing periodontitis in man. Journal of Clinical Periodontology 6 , 278-307.

Vichyanond, P., Howard, C. P. \& Olson, L. C. (1983). Eikenella corrodens as a cause of thyroid abscess. American Journal of Diseases of Children 137, 971-973.

Weiss, A. A. \& HewLETT, E. L. (1986). Virulence factors of Bordetella pertussis. Annual Review of Microbiology 40, 661-686.

YAMAZAKI, Y., EBISU, S. \& OKADA, H. (1981). Eikenella corrodens adherence to human buccal epithelial cells. Infection and Immunity 31, 21-27.

Yamazaki, Y., Ebisu, S. \& OKada, H. (1988). Partial purification of a bacterial lectinlike substance from Eikenella corrodens. Infection and Immunity 56, 191-196.

YAnisch-PerRon, C., Vieira, J. \& Messing, J. (1985). Improved M13 phage cloning vectors and host strains: nucleotide sequences of the M13 mp18 and pUC19 vectors. Gene 33, 103-119. 